Multidisciplinary

SCIENTIFIC JOURNAL OF

MARITIME RESEARCH

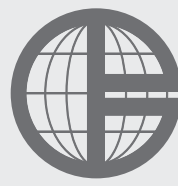

University of Rijeka

Faculty of Maritime

Studies Rijeka
Multidisciplinarni

znanstveni časopis

POMORSTVO

\title{
The Perspectives of Port Integration into the Global Supply Chains - The Case of North Adriatic Ports ${ }^{1}$
}

\author{
Alen Host, Helga Pavlić Skender, Petra Adelajda Mirković \\ University of Rijeka, Faculty of Economics, Ivana Filipovića 4, 51000 Rijeka, Croatia, e-mail: alen.host@efri.hr; helga.pavlic.skender@efri.hr; \\ petra.adelajda.mirkovic@efri.hr
}

\section{ABSTRACT}

Globalization, offshoring and the notable growth of containerization have changed the maritime transport and logistics chains. Ports became integral part of complex supply chains and serve as a logistics centres, add value, link flows and influence the supply chain patterns and processes. The port competitiveness is determined by its in-house strengths such as efficient freight handling and hinterland connections and by its position and links in the global supply chains. The aim of this paper is to investigate the importance of port integration in the supply chains overall and to analyse how North Adriatic Ports are integrated into the supply chains. The analysis is based on the sample of 939 firms aggregated by ports regions and classes level within Section H (Nace Rev.2). The assumption is that if the business cycle of all firms (classes) included in the port supply chain is correlated, it can indicate that the port is integrated in the supply chain. The results of our analysis are ambiguous, where the correlation is rather negative than positive. This paper provides the conceptual framework and outline the significance of this investigation for port operators, shipping lines, forwarders and other stakeholders.

\section{ARTICLE INFO}

Review article

Received 2 May 2018

Accepted 28 May 2018

Key words:

Port integration

Global supply chains

North Adriatic ports

NAPA

\section{Introduction}

During the last two decades, ports have transformed their role from the traditional regional gateways to the place where essential value adding, and logistics activities are taking place. Ports became integral part of a complex supply chains, serve as a logistics centers and influence the supply chain patterns and processes. Ports have played, and will continue to play, much more decisive roles in the sustainability of logistics and supply chains. Out of the numerous nodes in global supply chains, ports play an essential role in enabling the continuous flow of shipments between supply chain entities.

An increasing volume of research focuses on port integration into supply chains and its impact on port performance and competitiveness, however a little empirical

\footnotetext{
This research has been supported by the University of Rijeka (UNIRI), project Transport and logistics in the function of incorporating firms into regional production networks and international trade flows, code ZP UNIRI 2/17.
}

evidence exists in the case of North Adriatic ports. Thus, the purpose of this papers is to examine the North Adriatic ports (hereinafter NAPA) integration into the global supply chains and to analyse the perspectives of its integration.

From 2004 onwards, as the European Union started to grow eastwards, the role of re-assessment of port hinterland relationship became the core component in freight distribution (Notteboom and Rodrigue, 2007). The significant production facilities in the countries of Central and Eastern Europe have been established and thus the port integration of NAPA ports is supply chain became even more important.

It is noticeable that the NAPA ports are improving their connections with hinterlands, logistics infrastructures and inland transportation. Furthermore, instead of just cargo loading and unloading, North ports, especially Port of Koper are providing more diversified, and value-added services. However, NAPA ports should strengthen their connections with inland market, transport and logistics infrastructures, especially dry ports, in order to enhance their competitiveness. The NAPA ports should be able to 
fulfil a new role in the logistics era in the context of operating as parts of integrated global supply chain systems. As in Ng and Liu (2014), "a port-focal logistical system should be established, with ports being the focal points in the development of logistics and supply chains".

The remainder of the paper is structured as follows. Second chapter introduces the literature related to the port integration into supply chains. Data description and methodology is explained in fourth chapter. Chapter five discusses the results and policy implications and the sixth chapter presents concluding remarks.

\section{Literature Review}

The supply chain integration has become a major area of research, gaining increasing popularity, especially in the last two decades. Much work has been done on the analysis of the changing role of ports in supply chains (Carbone and Martino, 2003, Marlow and Paixão Casaca, 2003, Bichou and Gray, 2004, Notteboom and Rodrigue, 2007, Song and Panayides, 2008, Panayides \& Song, 2009, Woo, Pettit, Baresford, 2013, Loh and Thai, 2015, Bartholdi, Jarumaneeroj and Ramudhin 2016). Many authors emphasized the importance of port to integration in the supply chains, such as Bichou \& Gray (2004) who state that the role of port outpace the simple function of transshipment and that ports became a place for value added logistics. Panayides \& Song (2009) argue that ports should grow from the traditional functions of facilitating loading and discharging operations in order to become links in a complex logistics chain, hence the part of a global distribution network. According to Radhika (2012), the expansion of global supply chains changes the traditional role of ports from providers of transshipment services to an efficient distributor of products across the supply chain and integrated logistics service providers. Finally, Zuidwijk (2015) concludes that as global supply chains are becoming more complex, ports need to act as central nodes in organizational and information networks and not only be global hubs in logistics networks.

Nonetheless, in order to understand the port integration in supply chain it is important to define supply chains and the concept of the supply chain integration. As in Bichou and Gray (2004, p. 48) "supply chain is defined as a set of firms that pass materials forward; an alignment of firms that brings goods or services to market; or a network of organizations that, through upstream and downstream linkages, produce value in delivering products or services to the ultimate consumer". According to $\mathrm{Ng}$ and Liu (2014), in order to integrate in supply chains, ports have to improve their connections with hinterlands, and inland transport and logistics infrastructures. Thus, ports have to start to provide more diversified, and value-added services rather than just cargo loading and unloading and have to orient more to users from various industrial sectors, not just shipping lines. In 2008, Song and Panayides identified six parameters which indicate port integration in global supply chain such as the "use of technology for data sharing", "relationships with shipping lines", "value added services", "relationships with inland transport providers", "transport mode integration" and "channel integration practices and performance". In the later research Panayides \& Song (2009) made further contribution to the field by empirically developing measures of seaport integration in global supply chains. Previous six parameters are aggregated into four "terminal supply chain integration (TESCI)" parameters, including ICT systems, valueadded services, multimodal systems and operations, and supply chain integration practices. Their results indicate that the ICT system and supply chain integration practices have the most important impact in the supply chain integration.

Although this topic is highly relevant, there is a gap in the literature focusing on the NAPA ports integration in the supply chain. Port integration is highly important for small ports such as NAPA ports in order to become competitive and enhance its performance. Trupac and Twrdy (2014) analyzed the competitiveness of Port of Koper through supply chain integration. Authors state that the vision of the management of the Port of Koper is to become the most important logistic center for Central and Eastern European countries through the inland connection and ongoing regional center projects. Authors state that for a port, the inland part is as important as the sea part because the part is always standing within a supply chain network. Furthermore, Prah and Kramberger (2014) were studying how do port-cities integrate port and urban functions in the case of port-city of Koper using spatial analysis with GIS tools. Their results show that urban and port functions in Koper are clustered, with highest density of port functions in newer area of central activities east of the old town. As far as we know, there was no research focusing on NAPA ports in the context of supply chain integration. Thus, in this paper we investigate the integration of NAPA ports in the supply chain.

\section{North Adriatic Ports (Port of Rijeka, Port of Koper, Port of Trieste)}

The North Adriatic ports are positioned in the northern part of the Adriatic Sea, which penetrates deep into the center of the Europe, providing the cheapest maritime route from the Far East, via Suez, to Europe (NAPA, 2011). NAPA ports present a significant hub in the sea transport of Central and East European countries.

\subsection{Port of Rijeka}

As Croatia joined the European Union, the market position of the Port of Rijeka and Rijeka Gateway became comparable with other competitive ports and gateways (Perić Hadžić, Župarić, Đeverlija, 2016). The main activities of Port of Rijeka are traditional port activities such as loading, unloading, transshipment, warehousing, trans- 
port of general cargo, timber, liquid and bulk cargo, grain cargo, cattle, fruits, wheat, various crops, docking and undocking ships etc. (Perić Hadžić, Župarić, Đeverlija, 2016). However, Port of Rijeka together with other members of supply chain offers other activities like transshipment of goods, warehousing, servicing covering and insuring cargo, transport vehicles and many others. All those activities indicate that Port of Rijeka is integrating in the supply chain, however on the low level. The Port of Rijeka is equipped to handle all types of goods. The terminals of Port of Rijeka are: General Cargo Terminal, Grain Terminal, Liquid Cargo Terminal, Container Terminal Brajdica, Dry Bulk Cargo Terminal, Bakar Goranin Ro-Ro Terminal, Škrljevo Terminal, Raša Bršica Terminal, Passenger Port Terminal (Port of Rijeka, 2017). In 2017 the Port of Rijeka achieved the total throughput of up to 12.615 .066 tons of handled cargo. The container terminal handled 249.975 TEU which is approximately $40 \%$ more compared to 2007. Although the total throughput, especially container traffic increased in the last ten years, the Port of Rijeka is lagging behind the Port of Koper primary because its specific position in the city center and poor connection with the hinterland, secondly it doesn't use advanced ICT system. Because of those two parameters it's not able to fully adapt supply chain integration practices. Another obstacle which makes the port less competitive is the disconnection with the Adriatic Baltic corridor, mainly Port of Rijeka unlike the rest of NAPA ports is the only one which is not included in the Adriatic Baltic corridor which is one of the most important trans-European road and railway axes in Central Europe. "The corridor runs from the Baltic sports of Gdansk, Gdynia, Szczecin and Świnoujście in the north, to the Adriatic ports of Koper, Trieste, Venice and Ravenna in the south, taking in the industrial regions of Central and Southern Poland, before straddling the Czech, Slovakian and Austrian/Slovenian boarders on its way south to Italy and Slovenia" (European Commission, 2017).

\subsection{Port of Koper}

The Port of Koper is the appropriate equipped for handling various types of goods such as general cargo, livestock, containers, cars and Ro-Ro, timber, dry bulks, ores and coal, liquid cargo, alumina, and cereals (Prah, Kramberg, 2014). In 2017 the Port of Koper achieved the total traffic of up to 23.366.959 tons of handled cargo. The container terminal handled 911.528 TEU (Port of Koper, 2017). The traffic in transit has the dominant share whereas the exports and imports through the Port of Koper represent a minor share. Port of Koper performs most of its services for hinterland countries like Austria, Hungary, Slovakia, Czech Republic, Poland, southern Germany, Italy, Switzerland, Croatia, Bosnia and Herzegovina, Serbia and Ukraine and Russia (Trupac, Twrdy, 2014). The Port of Koper Authority plans to focus on the cooperation of the Port of Koper with the existing inland terminals (logistic centers) and to establish new ones which would be po- sitioned between Eastern and Western Europe, thus to adapt the supply chain integration practices.

\subsection{Port of Trieste}

The Port of Trieste terminals are equipped with modern technology for handling, transportation and storage at the service of all types of cargo: containerized cargo, fruit and vegetables, coffee, grains, metals, engines, steel and chemical products, timber, dry and liquid bulk, crude oil and derivative products. However, the oil terminal, which supplies the main refineries in Central Europe, is the biggest generator of traffic in the Port of Trieste.

In 2016/2017 the Port of Trieste achieved the total traffic of up to 61.955.405 tons of handled cargo, however, the container terminal handled 616.156 TEU (Port of Trieste, 2017).

Rail services and links play a crucial role in the logistics chain centering around the Port. Actually, Trieste is the most important railway port in Southern Europe, with 70 $\mathrm{km}$ of track serving all the docks and making it possible to assemble freight trains directly in the various terminals. (Port of Trieste, 2017).

Although, as mentioned above, the position of NAPA ports provides the cheapest/shortest sea route from the Far East to Europe, the cargo to central and eastern Europe is still sent to the western European ports of Rotterdam, Antwerp and Hamburg as showed in the Map 1. The Multiport gateway regions number 1, 2 and 3 present the main shipping routes and are the best equipped and developed logistics centers, highly integrated in the global supply chains.

Furthermore, all the Northern Adriatic ports are all small, which are, on one hand competing, and on the other hand, holding the position of common competition, acting as a gathered port system in relation to other traffic routes through where goods from Middle European countries are transported (Vilke, 2005: 85 in Naletina, Baković and Damić, 2017).

According to the theory mentioned in the second section of the paper, in order to port integrate in the supply chain it is important to satisfy four parameters, ICT systems, value-added services, multimodal systems and operations, and supply chain integration practices (Panayides \& Song, 2009). The NAPA ports are still not ICT developed and do not fully exploit the supply chain practices. Among the above-mentioned NAPA ports, Port of Rijeka is dealing with the weak railway and road connections of the Port of Rijeka and insufficient low-quality facilities on the hinterland which disable the appropriate integration of the port in the supply chains.

\section{Methodology and Data}

As in Bichou and Gray (2004, p. 48) "supply chain is defined as a set of firms that pass materials forward; an alignment of firms that brings goods or services to mar- 


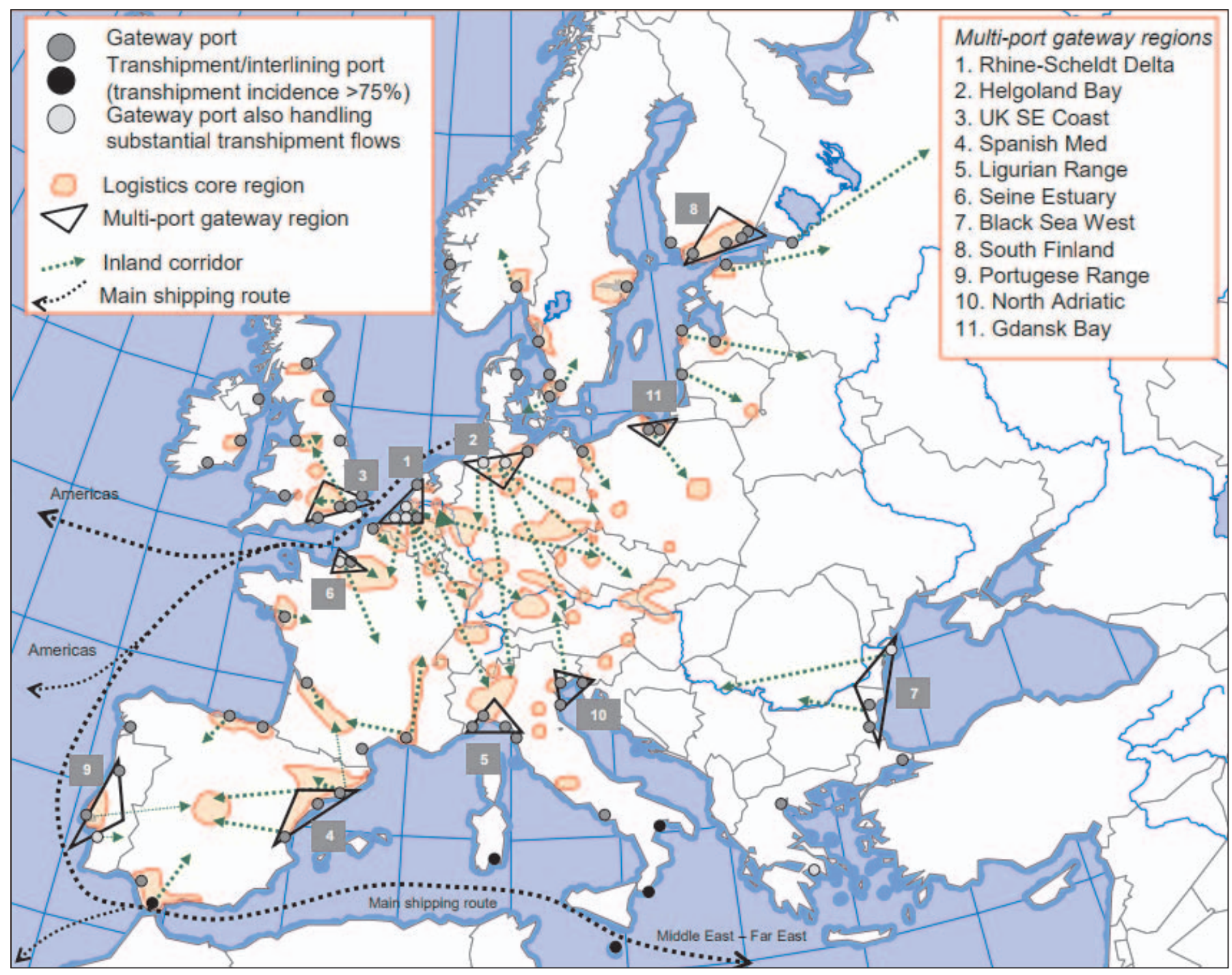

Map 1 European Container port system and logistics core regions in the hinterland

Source: Notteboom, 2009

ket". The assumption of our research is that if the business cycle of all firms (classes) included in the port supply chain is correlated, it can indicate that the port is integrated in the supply chain, thus in our research we calculate the correlation between classes within port regions. As the proxy variable for business cycle we use sales growth. We calculate the difference between two successive periods to obtain sales growth of all classes included in the sample.

Our sample includes data for 939 firms aggregated by port regions and group/class for three North Adriatic ports (Port of Rijeka, Port of Koper and Port of Trieste). We distinguish between 9 classes within 5 groups ( 3 divisions) from Section H. Firm-level data for firms registered in one of the 9 classes was obtained from Bureau van Dijk Amadeus database and include the period from 2007 to 2016. The data of the firms are aggregated in the following classes: 4920 Freight rail transport, 4941 Freight transport by road, 4942 Removal services, 5020 Sea and coastal freight water transport and 5210
Warehousing and storage, 5221 Service activities incidental to land transportation, 5222 Service activities incidental to water transportation, 5224 Cargo handling, 5229 Other transportation support activities. Table 1 contains descriptive statistics of all used variables expressed in relative values.

The first column in Table 1 presents the NAPA port regions. As we are separately analyzing the integration of each NAPA port in the supply chain, we aggregated firms on the regional level distinguishing it between divisions, groups and classes (column 2-4). The fifth column describes the type of business in each class. The column "Mean" shows the negative sales growth on average in the case of the firms within class 4941 and 5254 in Port of Koper region and Port of Trieste region, while in the case of Port of Rijeka the sales growth is on average positive in both classes. However, the negative sales growth on average in Port of Rijeka is noted in classes 4920 and 5210. When we look at the class 5020, Sea and coastal freight 
Table 1 Descriptive statistics

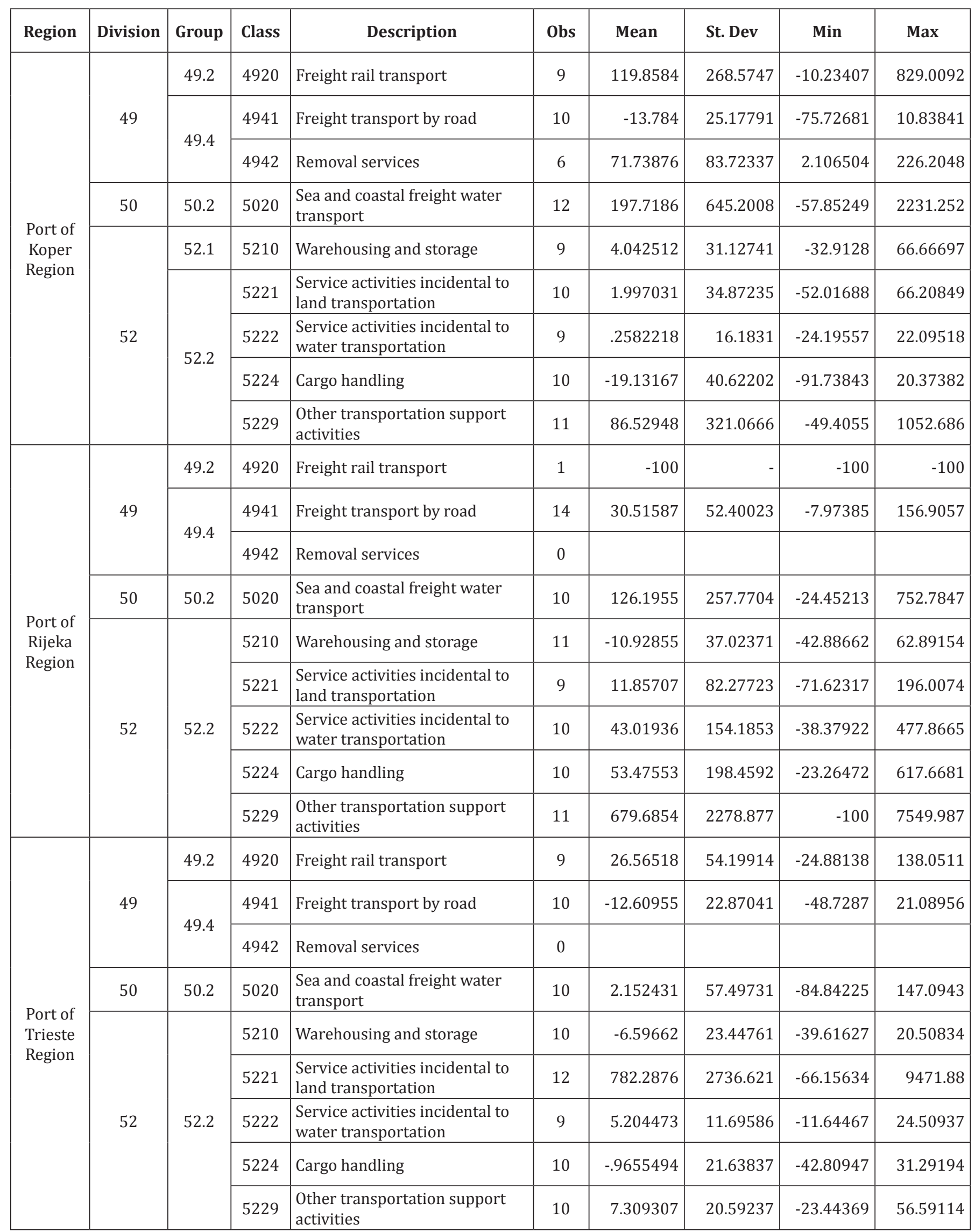


water transport, the average sales growth is the highest in the Port of Koper, however, the standard deviation is also the highest between the firms in the class 5020 in the Port of Koper.

\section{Results and Discussion}

The Table 2 represents the coefficients of correlations between all the classes included in the Port of Rijeka supply chain. However, the coefficients are rather negative than positive indicating the negative relationship between classes. The only positive but weak correlation is between classes 5210, Warehousing and storage and 5229, Other transportation support activities. These results are showing that the classes are rather disintegrated than integrated.
In table 3 are presented coefficients of correlation between classes in the Port of Koper region. In the contrast of Port of Rijeka, classes in Port of Koper are correlated. The highest correlation can be seen between classes 5210, Warehousing and storage and 5222 Service activities incidental to water transportation. The classes 4941, Freight transport by road and 4942, Removal services are positively but weakly correlated. However, this can be an indicator that Port of Koper, in this situation is more integrated in the supply chain than Port of Rijeka.

In the case of Port of Trieste, the situation is similar to the Port of Koper and Rijeka. There is no evident strong correlation between classes. The results indicate there is no evident integration when analysing the sales growth of firms included in port operations.

Table 2 Correlation (Port of Rijeka Region)

\begin{tabular}{|l|c|c|c|c|c|c|c|}
\hline & 4941 & 5020 & 5210 & 5221 & 5222 & 5224 & 5229 \\
\hline 4941 & 1.0000 & & & & & \\
\hline 5020 & -0.4179 & 1.0000 & & & & \\
\hline 5210 & -0.1114 & -0.1691 & 1.0000 & & & & \\
\hline 5221 & -0.4804 & -0.3161 & -0.1712 & 1.0000 & & & \\
\hline 5222 & -0.4416 & -0.5076 & -0.0284 & -0.0544 & 1.0000 & & \\
\hline 5224 & -0.2900 & -0.0039 & 0.0484 & -0.2140 & -0.1482 & 1.0000 & \\
\hline 5229 & -.00914 & -0.5748 & $\mathbf{0 . 3 2 1 2}$ & $\mathbf{0 . 6 0 3 6}$ & -0.1209 & 0.0741 & 1.0000 \\
\hline
\end{tabular}

Source: Author's calculation

Table 3 Correlation (Port of Koper Region)

\begin{tabular}{|c|c|c|c|c|c|c|c|c|c|}
\hline & 4920 & 4941 & 4942 & 5020 & 5210 & 5221 & 5222 & 5224 & 5229 \\
\hline 4920 & 1.0000 & & & & & & & & \\
\hline 4941 & -0.1158 & 1.0000 & & & & & & & \\
\hline 4942 & 0.3847 & 0.6088 & 1.0000 & & & & & & \\
\hline 5020 & -0.0623 & -0.0039 & -0.4275 & 1.0000 & & & & & \\
\hline 5210 & -0.4856 & -0.4544 & -0.6079 & -0.4131 & 1.0000 & & & & \\
\hline 5221 & 0.1885 & -0.3626 & -0.4246 & -0.3026 & 0.5253 & 1.0000 & & & \\
\hline 5224 & 0.1509 & 0.4962 & 0.1497 & 0.3178 & -0.2329 & -0.3908 & -0.4552 & 1.0000 & \\
\hline 5229 & -0.6382 & -0.0346 & 0.0761 & -0.2408 & 0.1272 & -0.2273 & 0.4557 & -0.7013 & 1.0000 \\
\hline
\end{tabular}

Source: Author's calculation

Table 4 Correlation (Port of Trieste Region)

\begin{tabular}{|c|c|c|c|c|c|c|c|c|}
\hline & 4920 & 4941 & 5020 & 5210 & 5221 & 5222 & 5224 & 5229 \\
\hline 4920 & 1.0000 & & & & & & & \\
\hline 4941 & -0.1397 & 1.0000 & & & & & & \\
\hline 5020 & -0.2873 & -0.5555 & 1.0000 & & & & \\
\hline 5210 & -0.0819 & 0.2716 & 0.3175 & 1.0000 & & & & \\
\hline 5221 & -0.3071 & $\mathbf{0 . 4 6 9 8}$ & 0.0309 & $\mathbf{0 . 5 8 4 0}$ & 1.0000 & & & \\
\hline 5222 & 0.3577 & -0.0813 & -0.5014 & -0.5438 & -0.4175 & 1.0000 & & \\
\hline 5224 & 0.3937 & -0.1179 & -0.0198 & -0.3116 & 0.1932 & 0.3861 & 1.0000 & \\
\hline 5229 & 0.3169 & -0.4529 & -0.2043 & -0.5775 & -0.2410 & 0.3494 & 0.2222 & 1.0000 \\
\hline
\end{tabular}

Source: Author's calculation 
Figure 1 represents the graphical analysis of the growth sales of each class in the port of Rijeka, Koper and Trieste regions.

The graphical analysis is showing us the ambiguous results. In the Port of Rijeka, the classes are oscillating similarly except in the case of warehousing where we notice the growth, while in the case of the Port of Trieste region the classes are not synchronized. In the case of Port of
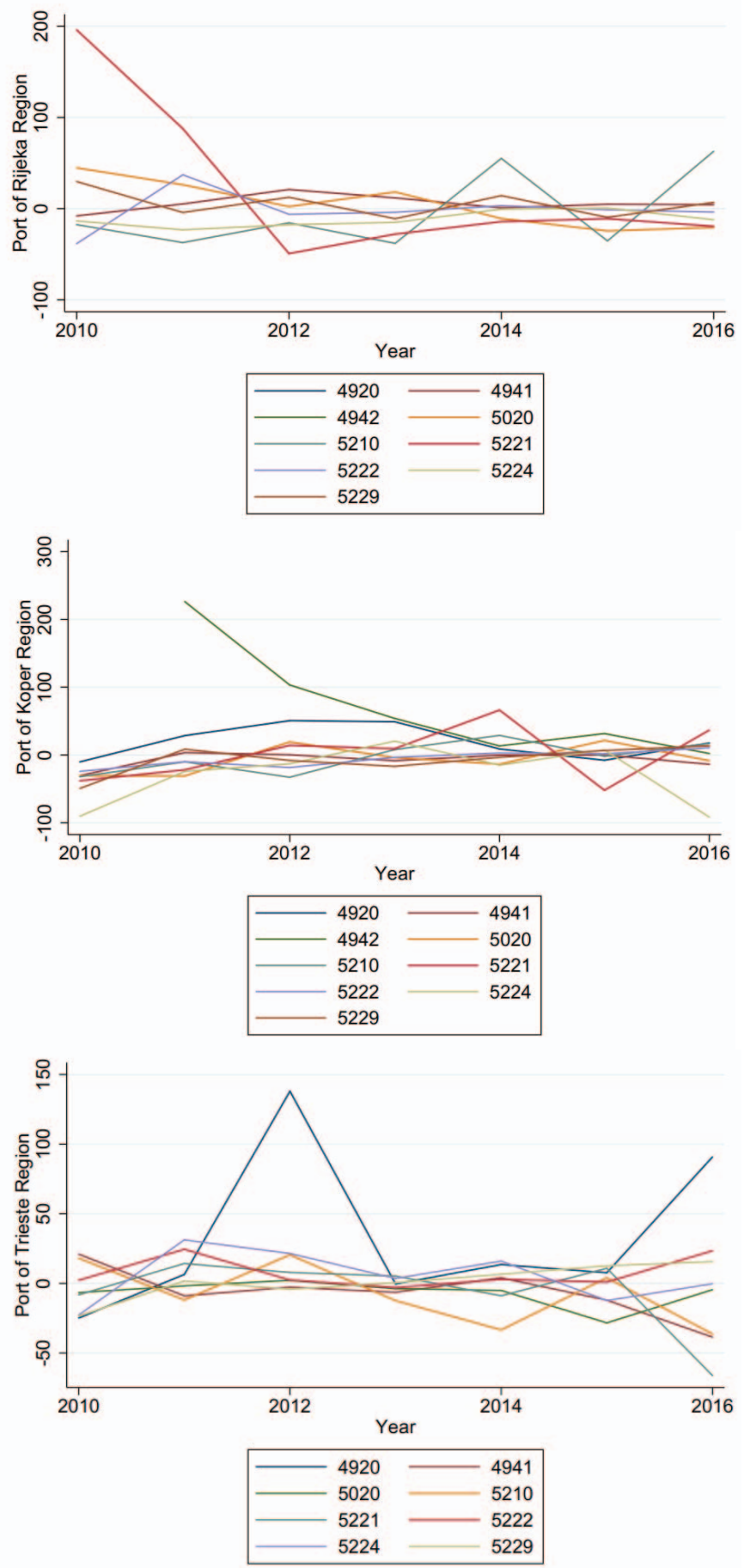

Figure 1 Sales growth in ports regions on class level in the period 2007-2016 (\%)
Koper region its noticeable the decline in cargo handling and the growth in the class Service activities incidental to land transportation. These results confirm the Decruet and Horts (2009) statement that there is a higher proportion of transport integration in northern Europe than "in southern Europe which is the historical and geographical setting in which northern European ports developed over time". NAPA ports are weakly connected with the hinterland which is important in the distribution of intermodal operators and forwarders.

\section{Conclusion and Policy Implication}

The new role of the ports and its integration into the supply chain is taking the attention in the last two decades. Today the ports are not just considered as the traditional regional gateways, but rather as the place where important value adding, and logistics activities are taking place. Ports today serve as a logistics centers and affect the supply chain processes and patterns thus being the integral part of a complex supply chains. The port integration is relevant because the port productivity and performance are related to the effectiveness of the whole supply chains (Panayides \& Song, 2009). As the European Union is enlarging eastwards, there is the opportunity for North Adriatic port to take their market position and become more competitive in relation to North European ports. This can be done by the by the application of supply chain integration practices. The results of our analysis are however indicating that the NAPA ports are not yet highly integrated info the supply chain. According to the theory, the NAPA ports should improve their facilities, port-hinterland connections and ICT system in order to integrate in the supply chain. This paper contributes to the area that is highly topical and relevant to developments taking place in maritime logistics, transportation and NAPA port development. Although the NAPA ports are introducing new connectivity projects, especially Port of Rijeka, there is much to be done in order to integrate in supply chain. Finally, ports can not integrate by them self, which mean that all stakeholders involved in port/transport operation must act as the common system, integrating together and this is mainly important for the transport policy makers. This paper provides the conceptual framework and outline the significance of this investigation for port operators, shipping lines, forwarders and other stakeholders.

\section{Acknowledgement}

This work has been fully supported by the University of Rijeka under the project ZP UNIRI 2/17. An earlier version of this paper was presented at the International Multidisciplinary Conference on Sea, Transport and Logistics 2017, organized by the Port of Rijeka Authority and the Faculty of Maritime Studies in Rijeka. The authors are thankful to the conference organizers, paper reviewers and participants for their valuable suggestions which shaped the better version of the paper. 


\section{References}

[1] Bartholdi III, J.J., Jarumaneeroj, P., Ramudhin, A.: A new connectivity index for container ports, Maritime Economics \& Logistics, Vol. 18, pp. 231-249, 2016.

[2] Bichou, K., Gray, R.: A logistics and supply chain management approach to port performance measurement, Maritime Policy \& Management, Vol. 31, pp. 47-67, 2004.

[3] Bureau van Dijk AMADEUS, 2017, http://amadeus.bvdep. com (15.11.2017).

[4] Carbone, V., Martino, M. D.: The changing role of ports in supply-chain management: An empirical analysis, Maritime Policy \& Management, Vol. 30, pp. 305-320, 2003.

[5] Ducruet, C., Van der Horst, M.: Transport Integration at European Ports: Measuring the Role and Position of Intermediaries, EJTIR, Vol. 9 (2), pp. 121-142, 2009.

[6] Loh, H.S., Thai, V.V.: Cost Consequences of a Port-Related Supply Chain Disruption, The Asian Journal of Shipping and Logistics, Vol. 31 (3), pp. 319-340, 2015.

[7] Marlow, P. B. \& Paixão Casaca, A. C.: Measuring lean ports performance, International Journal of Transport Management, Vol. 1, pp. 189-202, 2003.

[8] Naletina, D. Baković, T., Damić, M..: Competitiveness of Port of Rijeka, Proceedings of the International Conference Theory and Applications in the Knowledge Economy, pp. 682-696, 2017.

[9] NAPA Container Market Study, MDS, Transmodal limited, 2011, http:// www.its-napa.eu, 02.11.2017.

[10] Notteboom, T. Economic analysis of the European seaport system, https://www.espo.be/media/espopublications/ITMMAEconomicAnalysisoftheEuropeanPortSystem2009.pdf, 2009.

[11] Notteboom, T., Rodrigue, J.-P.: Containerisation, Box Logistics and Global Supply Chains: The Integration of Ports and Liner Shipping Networks, Maritime Economics and Logistics, Vol. 10, pp. 152-174, 2008.

[12] Notteboom, T., Rodrigue, J.-P.: Re-Assesing Port-Hinterland Relationship in the Context of Global Commodity Chains, 2007, Ports, cities, and global supply chains, Routledge, pp. 51-66, 2007.

[13] Ng, A. K. Y., Liu, J. J.: Port-Focal Logistics and Global Supply Chains, Palgrave Macmillan, 2014.
[14] Panayides, P. M. \& Song, D.-W.: Port integration in global supply chains: Measures and implications for maritime logistics, International Journal of Logistics: Research and Applications, Vol. 12, pp. 133-145, 2009.

[15] Perić Hadžić, A., Župarić, L., Đeverlija, S.: Analysis of the multiplicative effects of the Port of Rijeka, Scientific Journal of Maritime Research, Vol. 30, pp. 113-119, 2016.

[16] Ports of Rijeka, 2017, http://www.portauthority.hr/en/infrastructure/terminals (20.11.2017)

[17] Port of Koper, 2017, https://www.luka-kp.si/eng/311 (20.11.2017)

[18] Port of Trieste, 2017, http://www.porto.trieste.it/wp-content/uploads/2017/04/Sintesi_Statistiche_-ESPO_GennaioDicembre_2017.pdf (20.11.2017)

[19] Port of Trieste http://www.porto.trieste.it/eng/port/railintermodal-network (20.11.2017)

[20] Prah, K., Kramberger, T. Studying integration of port and urban functions in port-city of Koper, using spatial analysis techniques and GIS tools, 2014, (pdf) http://www.projetdevport.fr/en/PDF/21.pdf.

[21] Radhika, D.: The new role of seaports as integral parts of global supply chains, EXCEL International Journal of Multidisciplinary Management Studies, Vol. 2 (4), pp. 131-144, 2012.

[22] Song, D.-W., Panayides, P.M.: Global supply chain and port/ terminal: integration and competitiveness, Maritime Policy and Management: The flagship journal of international shipping and port research, Vol. 35 (1), pp. 73-87, 2008.

[23] Woo, S-H., Pettit, S.J., Beresford, A.K.C.: An assessment of the integration of seaports into supply chains using a structural equation model, Supply Chain Management: An International Journal, Vol. 18 (3), pp. 235-252, 2013.

[24] Trupac, I. and Twrdy, E.: More Competitiveness of the Port of Koper through Supply Chain Integration, Promet Traffic\&Transportation, Vol. 22 (4), pp. 251-257, 2014.

[25] Twirdy, E., Batista, M.:Port Competition in North Adriatic, Naše more, Vol. 61 (3-4), pp. 47-51, 2014.

[26] Vilke, S.: Koncepcija razvitka sjevernojadranskih luka Rijeke, Kopra i Trsta. Pomorski zbornik, Vol. 43 (1), pp. 85112, 2005. 